\title{
Dostęp oskarżonego pozbawionego wolności do kasacyjnego etapu postępowania karnego
}

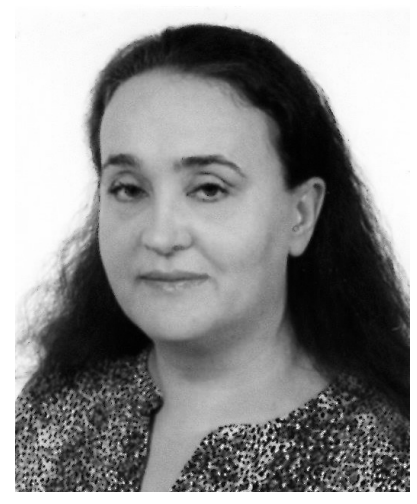

\section{Małgorzata Wąsek-Wiaderek \\ Kierownik Katedry Postępowania Karnego na Katolickim Uniwersyte- cie Lubelskim Jana Pawła II, sędzia Sądu Najwyższego orzekający w Izbie Karnej, autorka licznych publikacji z zakresu prawa karnego procesowego oraz ochrony praw człowieka w postę- powaniu karnym. \\ $\square$ belziuk@kul.pl \\ https://orcid.org/oooo-0001-9761-3177}

\section{The Access of an Accused Deprived of Liberty to the Cassation Stage of Criminal Proceedings}

\begin{abstract}
The article provides arguments supporting the thesis that the current regulations of the Code of Criminal Procedure do not guarantee full access to the cassation stage of the criminal proceedings for the accused deprived of liberty and represented by an ex officio defence counsel. In order to lodge a cassation appeal the accused is required to file a motion for written reasons of the appellate judgment within the prescribed time-limit indicated in Article $524 \S 7$ second sentence of the Code of Criminal Procedure. It is argued that in order to fulfil this requirement the accused must have fully effective right to acquire the content of the judgment or to take an informed decision to waive this right. The Author argues that this standard is not provided for by the current regulation of the Code of Criminal Procedure. The analyses take into account standards stemming from the case-law of the European Court of Human Rights.
\end{abstract}

Słowa kluczowe: kasacja, postępowanie karne, dostęp do kasacyjnego etapu postępowania karnego, Europejska Konwencja Praw Człowieka, prawo do rzetelnego procesu.

Key words: cassation appeal, criminal procedure, access to the cassation stage of the criminal proceedings, European Convention on Human Rights, fair trial

https://doi.org/10.32082/fp.v4i54.277

\section{Uwagi wprowadzajace}

Nie ma wątpliwości, że z faktu pozbawienia oskarżonego wolności w toku postępowania karnego wynikają istotne utrudnienia w realizowaniu prawa do obrony $\mathrm{i}$ innych uprawnień procesowych.
Z tego też względu w dyrektywie unijnej w sprawie pomocy prawnej $\mathrm{z}$ urzędu dla podejrzanych i oskarżonych w postępowaniu karnym ${ }^{1}$

1 Dyrektywa Parlamentu Europejskiego i Rady (UE) 2016/1919 z dnia 
uznano, że spośród dwóch kryteriów warunkujących powstanie obowiązku zapewnienia oskarżonemu bezpłatnej pomocy prawnej: ubóstwa oraz „interesu wymiaru sprawiedliwości” (tzw. kryterium zasadności), to drugie jest spełnione w każdym przypadku, gdy oskarżony jest pozbawiony wolności (art. 4 ust. 4 b dyrektywy).

W Kodeksie postępowania karnego z 1997 r. aż do dnia 30 czerwca 2015 r. przewidziane było uregulowanie, zgodnie z którym sam fakt pozbawienia oskarżonego wolności skutkował obowiązkiem posiadania obrońcy przed sądem okręgowym jako sądem pierwszej instancji ${ }^{2}$. Również do tej daty obowiązywały dwa inne, ważne dla postępowania odwoławczego uregulowania, których celem było zniwelowanie negatywnych skutków pozbawienia oskarżonego wolności w czasie postępowania karnego. Po pierwsze, zgodnie $\mathrm{z}$ art. $419 \$ 2$ k.p.k., jeżeli oskarżony pozbawiony wolności nie był obecny przy ogłoszeniu na rozprawie orzeczenia kończącego postępowanie w sprawie, a nie miał obrońcy, orzeczenie to było mu doręczane wraz ze stosownymi pouczeniami o prawie, terminie i sposobie wniesienia środka zaskarżenia. Po drugie, jeżeli oskarżony wnioskował o doprowadzenie go na rozprawę odwoławczą i wyjątkowo sąd nie zdecydował o takim doprowadzeniu, uznając za wystarczającą obecność obrońcy, to wyznaczał oskarżonemu obrońcę z urzędu, jeżeli ten nie był reprezentowany przez obrońcę z wyboru. Jedynie ten ostatni przepis, chociaż w zmienionej postaci, obowiązuje obecnie, przy czym, zarówno w poprzednim stanie prawnym, jak i de lege lata, w razie nieuwzględnienia wniosku oskarżonego o doprowadzenie na rozprawę odwoławczą udział takiego obrońcy w tej rozprawie jest obligatoryjny ${ }^{3}$.

26 października 2016 r. w sprawie pomocy prawnej z urzędu dla podejrzanych i oskarżonych w postępowaniu karnym oraz dla osób, których dotyczy wniosek w postępowaniu dotyczącym europejskiego nakazu aresztowania, Dz.Urz. UE L 297 z 4.11.2016 r., s. 1 i n.

2 Krytycznie o nieprzywróceniu dawnego brzmienia art. 80 k.p.k. pomimo utrzymania fakultatywnej obecności oskarżonego na rozprawie na skutek nowelizacji k.p.k. z dni 11 marca 2016 r.: M. Smarzewski, Granice efektywności prawa do korzystania z pomocy obrońcy $w$ kontekście ostatnich nowelizacji KPK, „Monitor Prawniczy” 2016, z. 21, s. 1157.

3 Por. A. Sakowicz (w:) A. Sakowicz (red.), Kodeks postepowania karnego. Komentarz, Warszawa 2018, s. 1145; D. Świecki,
Na skutek wejścia w życie nowelizacji Kodeksu postępowania karnego wprowadzającej kontradyktoryjny model procesu karnego ${ }^{4}$ istotnej zmianie uległy reguły doręczania stronom wyroków. Ze względu na odejście od zasady obligatoryjnej obecności oskarżonego na rozprawie wprowadzono regułę doręczania wszystkim stronom wyroków wydawanych pod ich nieobecność (art. $100 \$ 3$ k.p.k. w brzmieniu obowiązującym od dnia 1 lipca 2015 r. do dnia 14 kwietnia 2016 r.). Było to rozwiązanie ze wszech miar słuszne i zgodne ze europejskimi standardami prowadzenia postępowania in absentia ${ }^{5}$. Niestety ustawodawca, cofając w 2016 r. modelowe zmiany k.p.k., ale pozostawiając jednocześnie w kodeksie regulacje dotyczące fakultatywności udziału oskarżonego w rozprawie, całkowicie zmienił zasady doręczania wyroków stronom, które nie były obecne przy ich ogłoszeniu. Ograniczając dalsze rozważania do wyroków wydawanych po przeprowadzeniu rozprawy odwoławczej, trzeba stwierdzić, że istnieją poważne argumenty na rzecz tezy, iż obecnie obowiązujące przepisy nie gwarantują oskarżonemu pozbawionemu wolności i reprezentowanemu przez obrońcę z urzędu możliwości skutecznego zainicjowania postępowania kasacyjnego. Wynika to przede wszystkim ze skutków stosowania obecnego brzmienia następujących przepisów: art. $100 \$ 3$, art. $422 \S 2$ a k.p.k. i art. 451 k.p.k.

\section{Przesłanki doręczenia prawomocnego wyroku sadu odwoławczego oskarżonemu pozbawionemu wolności}

Przepis art. $100 \$ 3$ k.p.k. w wersji obowiązującej od dnia 5 października 2019 r. ${ }^{6}$ stanowi, że wyrok

Czynności procesowe obrońcy i pełnomocnika w sprawach karnych, Warszawa 2018, s. 502. Por. m.in. Wyrok Sądu Najwyższego z dnia 19 lutego 2013 r., IV KK 200/12, OSNKW 2013, z. 4, poz. 32.

4 Ustawa z dnia 27 września 2013 r., Dz.U. z 2013 r., poz. 1247, ze zm.

5 Por. M. Wąsek-Wiaderek, Prawo oskarżonego do realizowania obrony na rozprawie $w$ świetle ostatnich zmian kodeksu postępowania karnego (w:) S. Steinborn, K. Woźniewski (red.), Proces karny w dobie przemian. Przebieg postępowania, Gdańsk 2018, s. 322-323.

6 Czyli po wejściu w życie nowelizacji z dnia 19 lipca 2019 r., Dz.U. z 2019 r., poz. 1694. 
doręcza się podmiotom uprawnionym do wniesienia środka zaskarżenia, jeżeli ustawa tak stanowi. Jedyną zmianą wprowadzoną nowelizacją z dnia 19 lipca 2019 r. jest zastąpienie słowa „odwoławczego” terminem „zaskarżenia”. Wobec tego nadal, podobnie jak na skutek zmian obowiązujących od dnia 15 kwietnia 2016 r. do dnia 4 października 2019 r., przepis ten $\mathrm{w}$ istocie odsyła do innych wskazanych w kodeksie podstaw doręczenia wyroku? ${ }^{7}$ Poza wyrokiem nakazowym, o którego doręczeniu oskarżonemu przesądza art. 505 k.p.k., jak również wyrokiem wydanym na posiedzeniu po rozpoznaniu wniosku o wznowienie postępowania (art. $547 \S 5$ k.p.k.), kodeks nie przewiduje wprost obowiązku doręczenia wyroku oskarżonemu. Wobec tego należy przyjąć, że przepisem, który reguluje jedyną podstawę do doręczenia wyroku sądu odwoławczego oskarżonemu, jest art. $422 \$ 2$ a k.p.k. odczytywany w związku z art. $100 \$ 3$ k.p.k. Niewątpliwie przepis art. $422 \$ 2$ a k.p.k. znajduje zastosowanie w postępowaniu odwoławczym z mocy art. $457 \S 2$ k.p.k. Wobec tego wyrok sądu odwoławczego należy doręczyć oskarżonemu po spełnieniu czterech warunków wskazanych art. $422 \$ 2$ a k.p.k.: 1) oskarżony jest pozbawiony wolności; 2) nie ma obrońcy; 3) złożył wniosek o doprowadzenie na termin rozprawy, na którym został ogłoszony wyrok; 4) nie był obecny podczas ogłoszenia wyroku. W myśl przepisów obowiązujących do dnia 30 czerwca 2015 r. o obowiązku doręczenia oskarżonemu wyroku przesądzało spełnienie jedynie trzech warunków, wymienionych w punktach 1, 2 i 4 (art. $419 \$ 2$ k.p.k. w brzmieniu obowiązującym do dnia 30 czerwca 2015 r.).

Należy przy tym zaznaczyć, że zgodnie z utrwaloną linią orzecznictwa Sądu Najwyższego z chwilą ogłoszenia prawomocnego wyroku sądu odwoławczego na rozprawie odwoławczej uznaje się, iż oskar-

7 Na gruncie art. $100 \$ 3$ k.p.k. w jego brzmieniu obowiązującym od dnia 15 kwietnia 2016 r. do dnia 4 października 2019 r. w orzecznictwie wyrażono słuszny pogląd, że podstawy do doręczenia oskarżonemu wyroku sądu odwoławczego należy poszukiwać w art. $524 \$ 1$ zd. 2 k.p.k., zaś obowiązek doręczenia takiego wyroku wprowadza art. $422 \$ 2$ a k.p.k., który poprzez art. $457 \$ 2$ k.p.k. ma odpowiednie zastosowanie w postępowaniu odwoławczym. Por. Postanowienie Sadu Najwyższego z dnia 22 czerwca 2016 r., III KZ 39/16, OSNKW 2016, z. 12, poz. 80. żony reprezentowany w tym postępowaniu przez obrońcę z urzędu staje się „oskarżonym, który nie ma obrońcy", w rozumieniu dawnego art. $419 \$ 2$ k.p.k. a obecnego art. $422 \$ 2$ a k.p.k. Oczywiście, zgodnie $\mathrm{z}$ art. $84 \$ 1$ k.p.k., obrońca $\mathrm{z}$ urzędu jest uprawniony do podejmowania czynności także po uprawomocnieniu się wyroku, jednak wówczas nie może skutecznie dochodzić wynagrodzenia za tę czynność ${ }^{8}$. Sąd Najwyższy słusznie przyjmuje, że skoro z art. 84 $\$ 2$ k.p.k. wynika obowiązek podejmowania obrony przez obrońcę z urzędu jedynie „do prawomocnego zakończenia postępowania”, to po ogłoszeniu prawomocnego wyroku przez sąd odwoławczy oskarżony nie jest reprezentowany w sprawie. Taka wykładnia art. $419 \$ 2$ k.p.k. oraz art. $84 \$ 2$ k.p.k. prowadziła przed dniem 1 lipca 2015 r. do przyjęcia jednolitego stanowiska, że oskarżonemu pozbawionemu wolności, który w postępowaniu odwoławczym korzystał z pomocy obrońcy z urzędu, należy zawsze doręczyć prawomocny wyrok tego sądu, jeżeli nie był obecny przy jego ogłoszeniu'. Oznaczało to, że siedmiodniowy termin do złożenia wniosku o uzasadnienie wyroku sądu odwoławczego, która to czynność otwierała drogę do wniesienia kasacji, dla oskarżonego pozbawionego wolności rozpoczynał swój bieg od doręczenia wyroku, a nie jego ogłoszenia na rozprawie pod nieobecność oskarżonego.

Jak już wskazano, również na gruncie obecnie obowiązującego stanu prawnego należy uznać, że z chwilą ogłoszenia prawomocnego wyroku kończącego postępowanie na rozprawie odwoławczej oskarżony pozbawiony wolności, który był w tym postępowaniu reprezentowany przez obrońcę z urzędu, „nie

8 Por. C. Kulesza, Obrońca (w:) C. Kulesza (red. tomu), P. Hofmański (red. nacz.), Strony i inni uczestnicy postępowania karnego. System Prawa Karnego Procesowego, t. 6, Warszawa 2016, s. 914; por. także Postanowienie Sądu Najwyższego z dnia 18 września 2013 r., V KZ 60/13, Lex nr 1363213. W praktyce powoduje to, że obrońcy wyznaczeni z urzędu z chwilą ogłoszenia prawomocnego wyroku przez sąd odwoławczy zaprzestają dalszych czynności na rzecz oskarżonego. 9 Por. m. in.: Postanowienie Sądu Najwyższego z dnia 3 lutego 2012 r., V KZ 1/12, OSNKW 2012, z. 6, poz. 58; Postanowienie Sądu Najwyższego z dnia 24 maja 2016 r., V KZ 19/16, Lex nr 2044504; Postanowienie Sądu Najwyższego z dnia 13 lutego 2017 r., III KZ 91/16, Lex nr 2238696. 
ma już obrońcy” w rozumieniu art. $422 \$ 2$ a k.p.k. ${ }^{10}$ Obecnie jednak nie skutkuje to obowiązkiem doręczenia oskarżonemu tego wyroku. Musi być bowiem spełniony dodatkowy warunek - złożenia przez oskarżonego wniosku o doprowadzenie na termin rozprawy, na którym był ogłoszony ten wyrok. Wprowadzenie tej dodatkowej przesłanki ma daleko idące konsekwencje w postaci istotnego ograniczenia oskarżonemu pozbawionemu wolności dostępu do kasacyjnego etapu postępowania. czonej czy przerwanej. Nie ma bowiem wątpliwości, że pod pojęciem „pierwszy termin rozprawy” użytym na przykład w art. $132 \$ 4$ k.p.k. należy rozumieć jedynie datę rozpoczęcia rozprawy, a nie wszystkie daty prowadzenia rozprawy głównej, w tym także po jej odroczeniu. Można więc argumentować, że jeżeli rozprawa odwoławcza została odroczona, zaś oskarżony pozbawiony wolności wnioskował o doprowadzenie na rozprawę, a nie na odroczony termin rozprawy, na którym został ogłoszony wyrok, to warunek $\mathrm{z}$ art. 422

\section{Sąd Najwyższy słusznie przyjmuje, że skoro z art. 84} $\$ 2$ k.p.k. wynika obowiązek podejmowania obrony przez obrońcę z urzędu jedynie „do prawomocnego zakończenia postępowania”, to po ogłoszeniu prawomocnego wyroku przez sąd odwoławczy oskarżony nie jest reprezentowany w sprawie.

W pierwszej kolejności należy rozważyć, czy złożenie wniosku o doprowadzenie na rozprawę odwoławczą, o którym mowa w art. 451 k.p.k., jest równoznaczne ze złożeniem wniosku o doprowadzenie na termin rozprawy odwoławczej, „na którym został ogłoszony wyrok” w rozumieniu art. $422 \$ 2$ a k.p.k. Wątpliwości $\mathrm{w}$ tym względzie wynikają z tego, że w art. $422 \S 2 \mathrm{a}$ k.p.k. nie użyto sformułowania „rozprawa, na której został ogłoszony wyrok”, tylko zwrotu „termin rozprawy"11. Trzeba zauważyć, że w innych przepisach kodeksu ustawodawca używa określenia „termin rozprawy" dla wskazania określonej daty procedowania na rozprawie, a nie kolejnych terminów rozprawy odro-

10 Por. Postanowienie Sądu Najwyższego z dnia 27 lutego 2018 r., III KZ 11/18, Lex nr 2450253; Postanowienie Sądu Najwyższego z dnia 3 kwietnia 2019 r., V KZ 7/19, Lex nr 2649798.

11 O niefortunnym brzmieniu tego przepisu w kontekście realizowania obrony na rozprawie głównej pisałam w: M. Wąsek-Wiaderek, Prawo oskarżonego..., dz. cyt., s. 311-325.
$\$ 2$ a k.p.k. nie został spełniony. Taką interpretację należy jednak odrzucić jako antygwarancyjną, chociaż odpowiada ona rezultatom wykładni językowej przepisu art. $422 \S 2$ a k.p.k. Wobec tego trzeba przyjąć, że złożenie „ogólnego” wniosku o doprowadzenie na rozprawę odwoławczą jest równoznaczne ze złożeniem także wniosku o doprowadzenie na termin rozprawy, na którym został ogłoszony wyrok, bez względu na to, czy oba terminy, tj. ten, którego dotyczył wniosek oskarżonego, i termin rozprawy, na której został ogłoszony wyrok, się pokrywają. Słuszny jest przy tym wyrażony w doktrynie pogląd, że również złożenie wniosku, o którym mowa w art. 451 k.p.k., po terminie, co skutkuje pozostawieniem go bez rozpoznania, należy uznać za spełnienie trzeciego warunku wskazanego w art. $422 \S 2$ a k.p.k. ${ }^{12}$ Podobnie

12 D. Świecki, Wniosek o sporzadzenie na piśmie i doręczenie uzasadnienia wyroku (w:) Konstrukcja apelacji jako środka odwoławczego w procesie karnym, Warszawa 2018, wersja 
należy potraktować sytuację, w której oskarżony po złożeniu stosownego wniosku został doprowadzony jedynie na termin rozprawy odwoławczej, w czasie której rozpoznawano środek odwoławczy, zaś nie został doprowadzony na samo ogłoszenie wyroku sądu odwoławczego ${ }^{13}$.

Zupełnie odmiennie kształtuje się sytuacja oskarżonego, który nie złożył wniosku o doprowadzenie na rozprawę odwoławczą, nie spełniając tym samym jednego z czterech warunków doręczenia mu wyroku wydanego na tej rozprawie. Kluczowe jest tu pytanie, czy w świetle gwarancji rzetelnego procesu dopuszczalne jest poczynione przez ustawodawcę założenie, że rezygnacja z udziału rozprawie odwoławczej skutkuje również rezygnacją z otrzymania przez pozbawionego wolności oskarżonego wyroku sądu odwoławczego ze wszystkimi tego konsekwencjami w postaci rozpoczęcia biegu terminu do złożenia „zapowiedzi kasacji”, czyli wniosku o doręczenie wyroku sądu odwoławczego $\mathrm{z}$ uzasadnieniem, od daty jego ogłoszenia pod nieobecność oskarżonego.

\section{3. (Nie)przewidywane konsekwencje niezłożenia wniosku o doprowadzenie na rozprawę odwoławcza}

Nie ma wątpliwości, że Konwencja o ochronie praw człowieka i podstawowych wolności ${ }^{14}$ nie zobowiązuje do wprowadzenia do systemu krajowego kasacyjnej kontroli prawomocnego wyroku wydanego w sprawie karnej. Takiego prawa nie da się też wyinterpretować $\mathrm{z}$ art. 2 Protokołu nr 7 do Konwencji ${ }^{15}$, regulującego prawo do odwołania się od wyroku. Przepis ten nakłada na państwa strony jedynie obowiązek wprowadzenia możliwości odwołania się od orzeczenia o winie i karze, a zatem w uproszeniu - dwuinstancyjności

elektroniczna; K. Eichstaedt, Komentarz aktualizowany do art. 422 kodeksu posteppowania karnego (w:) D. Świecki (red.), Kodeks postępowania karnego, t. 1: Komentarz aktualizowany, LEX/el., 2019, teza 28.

13 K. Eichstaedt, Komentarz..., dz. cyt.

14 Dz.U. z 1993 r., Nr 61, poz. 284, ze zm.; dalej powoływana jako „Konwencja” lub „EKPC”.

15 Dz.U. z 2003 r., Nr 42, poz. 364. Por. M. Wąsek-Wiaderek, Standard ochrony praw oskarżonego w świetle Europejskiej Konwencji Praw Człowieka (w:) C. Kulesza (red. tomu), P. Hofmański (red. nacz.), Strony i inni..., dz. cyt., s. 603-608. postępowania karnego. Ponadto dopuszcza sporą gamę wyjątków, w tym pozbawienie prawa do odwołania się od orzeczenia osoby skazanej w wyniku zaskarżenia wyroku uniewinniającego wydanego w pierwszej instancji ${ }^{16}$. Natomiast wyrażone w art. 6 ust. 1 Konwencji prawo do rzetelnego procesu niewątpliwie obejmuje kasacyjny etap postępowania karnego. W rezultacie, jeżeli ustawodawca zdecydował o wprowadzeniu do systemu prawnego dostępnego dla stron nadzwyczajnego środka zaskarżenia w postaci kasacji, to powinien jednocześnie zapewnić oskarżonemu możliwość efektywnego skorzystania $\mathrm{z}$ tego środka. O ile zatem na gruncie art. 6 Konwencji oskarżony nie ma prawa domagać się wprowadzenia kasacyjnej kontroli orzeczenia sądu odwoławczego do systemu prawnego, to ma prawo kwestionować zasadność lub proporcjonalność wszelkich uregulowań prawnych utrudniających mu zainicjowanie tego postępowania. Trybunał powtarza bowiem, że ograniczenia prawa dostępu do danego etapu postępowania karnego nie mogą podważać istoty tego prawa, muszą służyć usprawiedliwionym celom i pozostawać do nich w stosunku proporcjonalności ${ }^{17}$.

Dostęp do kasacyjnego etapu postępowania był wielokrotnie poddawany ocenie na skutek skarg kierowanych przeciwko Polsce do Europejskiego Trybunału Praw Człowieka. W pierwszej kolejności dotyczyły one praktyki weryfikowania ubóstwa oskarżonego ubiegającego się o wyznaczenie obrońcy z urzędu w celu rozważenia wniesienia kasacji ${ }^{18}$. Orzecznictwo ETPC istotnie przyczyniło się do zmiany praktyki w tym zakresie. Obecnie efektywność dostępu do obrońcy $\mathrm{z}$ urzędu w celu wniesienia kasacji nie jest w żaden sposób kwestionowana. W praktyce orzeczniczej Sądu Najwyższego, także pod wpływem standardów strasburskich, rozwiązano również problem wyznaczenia początku biegu terminu do wniesienia kasacji

16 O konwencyjnym prawie do zaskarżenia orzeczenia obszernie: S. Steinborn, Ograniczenia zaskarżalności wyroku wydanego w I instancji jako środek uproszczenia procesu karnego $w$ świetle prawa do dwuinstancyjnego postępowania (uwagi de lege lata i de lege ferenda), „Gdańskie Studia Prawnicze” 2005 , t. 13 , s. $368-374$

17 M. Wąsek-Wiaderek, Standard..., dz. cyt., s. 554.

18 Wyrok ETPC z dnia 18 grudnia 2001 r., R.D. v. Polska, skargi nr 29692/96 i 34612/97; Wyrok ETPC z dnia 13 września 2011 r., Wersel v. Polska, skarga nr 30358/04. 
wobec skazanego pozbawionego wolności, któremu doręczono opinię obrońcy o braku podstaw do wywiedzenia tego nadzwyczajnego środka zaskarżenia ${ }^{19}$.

Natomiast kwestia doręczania wyroku sądu odwoławczego i powiązana z nią problematyka daty początkowej liczenia terminu do wniesienia kasacji nie była dotychczas przedmiotem skarg do ETPC skierowanych przeciwko Polsce. Fakt ten nie może zaskakiwać, bowiem dopiero od dnia wejścia w życie nowelizacji k.p.k. z dnia 11 marca 2016 r., czyli od dnia 15 kwietnia 2016 r., zaistniał problem wskazany w tym opracowaniu. Analiza orzecznictwa ETPC ogłoszonego wobec nując samych terminów jako ograniczenia w dostępie do nadzwyczajnej kontroli orzeczenia ${ }^{21}$. W jednym z orzeczeńn ${ }^{22}$ Trybunał stwierdził wręcz, że nie musi przesądzać, czy w świetle art. 6 Konwencji oskarżonemu lub jego obrońcy należy doręczać wyrok sądu odwoławczego, bowiem w każdej sprawie kluczową kwestią jest ustalenie czy ogólne wymogi rzetelności postępowania zostały spełnione. Ostatecznie Trybunał uznał, że nie narusza art. 6 ust. 1 Konwencji brak doręczenia wyroku oskarżonemu reprezentowanemu przez obrońcę na rozprawie odwoławczej. Trzeba jednak uwzględnić specyficzne okoliczności tej sprawy. Po

\section{ETPC powtarza, że ograniczenia prawa dostępu} do danego etapu postępowania karnego nie mogą podważać istoty tego prawa, muszą służyć usprawiedliwionym celom i pozostawać do nich w stosunku proporcjonalności.

innych państw Rady Europy pozwala stwierdzić, że w odniesieniu do tej incydentalnej kwestii jest ono stosunkowo ubogie. W kontekście terminów do wniesienia środka zaskarżenia Trybunał bada przede wszystkim to, czy doręczenie orzeczenia wyznaczające początek biegu tego terminu było prawidłowe ${ }^{20}$, nie kwestio-

19 Por. m.in.: Wyrok ETPC z dnia 19 maja 2009 r., Kulikowski v. Polska, skarga nr 18353/03; Wyrok ETPC z dnia 19 maja 2009 r., Antonicelli v. Polska, skarga nr 2815/05. Szerzej na ten temat: P. Hofmański, S. Zabłocki, Kasacja w sprawach karnych a niektóre uwarunkowania wynikające z zobowiazań traktatowych (w:) A. Błachnio-Parzych i in. (red.), Problemy wymiaru sprawiedliwości karnej. Księga Jubileuszowa Profesora Jana Skupińskiego, Warszawa 2013, s. 378-390; M. Wąsek-Wiaderek, Proces karny a międzynarodowe standardy w dziedzinie praw człowieka (w:) P. Hofmański (red.), System Prawa Karnego Procesowego. Zagadnienia ogólne, t. 1, cz. 2, Warszawa 2013, s. 149-151.

20 Por. np.: Wyrok ETPC z dnia 25 czerwca 2009 r., Maresti v. Chorwacja, skarga nr 55759/07; Wyrok ETPC z dnia 3 listo- pierwsze, trzymiesięczny termin do wniesienia kasacji rozpoczynał bieg od daty ogłoszenia wyroku. Po drugie, inaczej niż w polskim systemie prawnym jej wniesienie nie było warunkowane uprzednim złożeniem wniosku o doręczenie wyroku z uzasadnieniem. Po trzecie, skazany nie interesował się wynikiem postępowania odwoławczego ani nie skontaktował się ze swoim obrońcą przez okres sześciu miesięcy od daty ogłoszenia wyroku. Te wszystkie okoliczności spowodowały orzeczenie, że skarżący Jodko miał zagwarantowane prawo dostępu do kasacyjnego etapu postępowania.

Wydaje się, że na kwestię dostępu do kasacyjnego etapu postępowania w polskim procesie karnym

pada 2009 r., Davran v. Turcja, skarga nr 18342/03; Wyrok ETPC z dnia 15 września 2016 r., Johansen v. Republika Federalna Niemiec, skarga nr 17914/10.

21 Pkt 37-38 wyroku w sprawie Maresti v. Chorwacja.

22 Decyzja ETPC z dnia 7 września 1999 r. o niedopuszczalności skargi Jodko v. Litwa, skarga nr 39350/98. 
trzeba spojrzeć z perspektywy konwencyjnej koncepcji dobrowolnego i w pełni świadomego zrzeczenia się prawa. W świetle stabilnego orzecznictwa Europejskiego Trybunału Praw Człowieka oskarżony może zrzec się uprawnienia składającego się na prawo do rzetelnego procesu, w tym samego prawa skorzystania ze środka odwoławczego ${ }^{23}$. Muszą być jednak spełnione następujące przesłanki: fakt zrzeczenia się musi być ustalony ponad wszelką wątpliwość; oskarżonemu podejmującemu decyzje o zrzeczeniu się uprawnienia muszą być zagwarantowane „minimalne zabezpieczenia odpowiadające wadze danego prawa", a ponadto zrzeczenie się nie może być sprzeczne z jakimkolwiek ważnym interesem publicznym ${ }^{24}$. Ponadto konsekwentnie wskazuje się, że warunkiem zrzeczenia się uprawnienia jest posiadanie pełnej informacji o możliwości skorzystania z niego, jak również możliwość przewidzenia konsekwencji takiego zrzeczenia się ${ }^{25}$.

Powstaje zatem pytanie, czy oskarżony pozbawiony wolności ma "prawo do doręczenia wyroku sądu odwoławczego", bowiem tylko wówczas można oceniać regulacje kodeksowe pod kątem spełnienia konwencyjnych warunków zrzeczenia się tego prawa. Pozostaje poza sporem, że oskarżony ma prawo poznać treść wyroku sądu odwoławczego. Ustawodawca przewidział dwie formy zrealizowania tego prawa: przez ogłoszenie wyroku na rozprawie odwoławczej, oraz - po spełnieniu warunków z art. $422 \$ 2$ a k.p.k. - doręczenie tego wyroku oskarżonemu. Skoro istnieje obowiązek doręczenia wyroku sądu odwoławczego w określonych warunkach, to oskarżony ma prawo do jego otrzymania, jeżeli te warunki spełni. Natomiast o zrzeczeniu się tego prawa w rozumieniu konwencyjnym można mówić jedynie wówczas, gdy oskarżony zostanie poinformowany o warunkach skorzystania $\mathrm{z}$ tego prawa

23 O warunkach skutecznego zrzeczenia się prawa do wniesienia apelacji por. Wyrok ETPC z dnia 29 kwietnia 2014 r., Natsvlishvili and Togonidze v. Gruzja, skarga nr 9043/05.

24 Por. w najnowszym orzecznictwie: Wyrok ETPC z dnia 4 kwietnia 2018 r., Correia de Matos v. Portugalia, skarga nr 56402/12, pkt 128; kluczowy dla tej kwestii jest wyrok ETPC z dnia 1 marca 2006 r., Sejdovic v. Włochy, skarga nr 56581/00, pkt 86-88.

25 M. Wąsek-Wiaderek, Standard ochrony..., dz. cyt., s. 538-539. i jest w stanie przewidzieć konsekwencje zrzeczenia się korzystania $\mathrm{z}$ danego uprawnienia.

Stosując powyższe konwencyjne wymogi zrzeczenia się prawa jedynie do prawa oskarżonego pozbawionego wolności do udziału w rozprawie odwoławczej, a więc też prawa do wysłuchania ogłoszonego wyroku, nie ma wątpliwości, że zakres informacji, jakie z mocy art. 451 k.p.k. są mu przekazywane, pozwala na podjęcie swobodnej i świadomej decyzji o dysponowaniu tym prawem. Natomiast istotne wątpliwości budzi założenie, że oskarżony pozbawiony wolności i reprezentowany przez obrońcę $\mathrm{z}$ urzędu przez sam fakt niezłożenia wniosku o doprowadzenie na rozprawę odwoławczą zrzeka się także prawa do otrzymania odpisu prawomocnego wyroku sądu odwoławczego ze wszystkimi tego konsekwencjami dla możliwości zainicjowania kasacyjnej kontroli orzeczenia, skoro nie jest prawidłowo pouczany o tych konsekwencjach. Oskarżony pozbawiony wolności, o ile nie zostanie o tym poinformowany przez obrońcę wyznaczonego $z$ urzędu, w chwili decydowania o nieskładaniu wniosku o doprowadzenie na rozprawę odwoławczą nie jest zazwyczaj świadomy tego, że obrońca nie ma obowiązku złożenia wniosku o doręczenie wyroku $\mathrm{z}$ uzasadnieniem w terminie siedmiu dni od daty jego ogłoszenia. Jak już wskazano powyżej, obowiązek ten wygasa z chwilą ogłoszenia prawomocnego wyroku sądu odwoławczego. Oskarżeni pozbawieni wolności pozostają więc w błędnym przekonaniu, że także $\mathrm{w}$ razie ich rezygnacji $\mathrm{z}$ uczestniczenia $\mathrm{w}$ rozprawie odwoławczej obrońca wyznaczony z urzędu podejmie czynności procesowe zmierzające do wniesienia kasacji. O treści art. $84 \$ 2$ zd. 1 k.p.k. oskarżony nie jest przecież informowany na żadnym etapie postępowania karnego. W stanie prawnym obowiązującym do dnia 14 kwietnia 2016 r. nieświadomość zakresu czasowego podejmowania czynności przez obrońcę z urzędu była w zasadzie irrelewantna dla oskarżonego, skoro jego nieobecność przy ogłoszeniu wyroku, jeżeli był pozbawiony wolności, zawsze skutkowała doręczeniem mu tego orzeczenia wraz ze stosownymi pouczeniami. Obecnie ma kluczowe znaczenie.

Oprócz omówionej nieświadomości co do zakresu czasowego obrony z urzędu oskarżony nie jest informowany w sposób prawidłowy i wyczerpujący o skutkach niezłożenia wniosku o doprowadzenie na rozprawę 
odwoławczą. W myśl obowiązujących przepisów jest on pouczany o treści art. $100 \$ 3$ k.p.k. przy okazji wezwania lub zawiadomienia o terminie rozprawy głównej (art. $353 \$ 4$ k.p.k.), zaś o treści art. $422 \$ 2 \mathrm{a}$ k.p.k. dwukrotnie: przy okazji doręczenia mu odpisu aktu oskarżenia (art. $338 \$$ la k.p.k.) oraz wraz z doręczeniem wezwania lub zawiadomienia o terminie rozprawy głównej (art. $353 \$ 4$ k.p.k.). Natomiast przepis art. 451 k.p.k., regulując autonomicznie dla postępowania odwoławczego kwestię złożenia wniosku o dopro- podstawie obowiązujących przepisów można argumentować, że obowiązek takiego pouczenia należy wywodzić $\mathrm{z}$ art. $353 \$ 4$ k.p.k. stosowanego odpowiednio w postępowaniu odwoławczym na podstawie art. 458 k.p.k. Nie jest to jednak wniosek oczywisty, bowiem przepis art. 451 k.p.k. reguluje zakres pouczenia w sposób autonomiczny, nakazując jedynie poinformowanie o możliwości złożenia wniosku o doprowadzenie, o terminie dokonania tej czynności i - co należy także wywodzić z treści tego przepisu - o skutkach jego

\section{Istotne wątpliwości budzi założenie, że oskarżony} pozbawiony wolności i reprezentowany przez obrońcę z urzędu przez sam fakt niezłożenia wniosku o doprowadzenie na rozprawę odwoławczą zrzeka się także prawa do otrzymania odpisu prawomocnego wyroku sądu odwoławczego ze wszystkimi tego konsekwencjami dla możliwości zainicjowania kasacyjnej kontroli orzeczenia, skoro nie jest prawidłowo pouczany o tych konsekwencjach.

wadzenie na rozprawę, nakazuje jedynie pouczyć oskarżonego o prawie i terminie do złożenia takiego wniosku wraz z doręczeniem mu zawiadomienia o przyjęciu apelacji. W rezultacie w praktyce oskarżony nie jest informowany o dalej idących skutkach niezłożenia wniosku, innych niż niedoprowadzenie na rozprawę odwoławczą, w szczególności o tym, że nie będzie mu doręczony wyrok wydany pod jego nieobecność ${ }^{26}$. Na

26 Na marginesie należy zauważyć, że w związku ze zmianą reguł doręczania wyroków Sąd Najwyższy wyinterpretował obowiązek pouczania oskarżonego o zmienionej treści art. $100 \$ 3$ k.p.k. oraz art. $422 \$ 2$ a k.p.k. z zasady lojalności procesowej. Ta linia orzecznictwa dotyczy jednak tylko postępowań prowadzonych w czasie obowiązywania niezłożenia w postaci możliwości przeprowadzenia rozprawy odwoławczej pod nieobecność oskarżonego. Można więc przyjąć, że zawiera kompletną regulację w zakresie pouczeń, nie zostawiając pola dla odpowiedniego stosowania art. $353 \$ 4$ k.p.k. Wobec takiego brzmienia przepisów w praktyce oskarżony nie jest ponownie informowany o tym, że niezłożenie wnio-

kilku reżimów doręczania wyroków. Por. w tym względzie Postanowienie Sądu Najwyższego z dnia 22 czerwca 2016 r. III KZ 39/16, OSNKW 2016, z. 12, poz. 80; Postanowienie Sądu Najwyższego z dnia 14 grudnia 2017 r., III KZ 56/17, Lex nr 2427121; Postanowienie sądu Najwyższego z dnia 23 stycznia 2019 r., III KZ 60/18, baza orzeczeń Supremus (www.sn.pl). 
sku o doprowadzenie na rozprawę odwoławczą będzie skutkowało niedoręczeniem mu wyroku.

Jest co najmniej wątpliwe, czy zapewnia możliwość świadomego i dobrowolnego zrezygnowania z prawa do otrzymania odpisu wyroku sądu odwoławczego to, że oskarżony jest informowany o treści art. $100 \$ 3$ k.p.k. oraz art. $422 \$ 2$ a k.p.k. na etapie postępowania przed sądem pierwszej instancji. Wymienione pouczenia są doręczane jedynie na wczesnym etapie postępowania pierwszoinstancyjnego, który od postępowania apelacyjnego może dzielić nawet kilkanaście lub kilkadziesiąt miesięcy. Skoro oskarżony otrzymuje pakiet zasady istnieje też obowiązek uzgodnienia z klientem ewentualnego odstąpienia od podjęcia działań zmierzających do wniesienia kasacji ${ }^{28}$. W praktyce niejednokrotnie obrońcy z urzędu, kierując się zasadami etyki, informują skazanych o treści wyroku sądu odwoławczego. $Z$ drugiej strony jednoznaczne brzmienie art. $84 \$ 2$ zd. 1 k.p.k. uprawnia obrońców do argumentowania, że wszelkie obowiązki wynikające ze stosunku obrończego wygasły z chwilą ogłoszenia prawomocnego wyroku przez sąd odwoławczy. Toteż w razie złożenia wniosku o przywrócenie terminu, o którym mowa w art. $524 \$ 1$ zd. 2 k.p.k., czyli ter-

\title{
Jest co najmniej wątpliwe, czy zapewnia możliwość
} świadomego i dobrowolnego zrezygnowania z prawa do otrzymania odpisu wyroku sądu odwoławczego to, że oskarżony jest informowany o treści art. 100

\author{
$\$ 3$ k.p.k. oraz art. $422 \$ 2$ a k.p.k. na etapie
} postępowania przed sądem pierwszej instancji.

ww. pouczeń przy okazji zawiadomienia lub wezwania na rozprawę główną, a nie otrzymuje ich ponownie w związku z zawiadomieniem o możliwości ubiegania się o doprowadzenie na rozprawę odwoławczą, to może wnioskować, że odstąpienie od udziału w tej drugiej nie powoduje dla niego żadnych negatywnych konsekwencji poza wskazanymi w art. 451 k.p.k. Co więcej, obrońca z urzędu ma obowiązek złożyć wniosek o uzasadnienie wyroku sądu pierwszej instancji w celu wywiedzenia apelacji. Podobny obowiązek nie uaktualnia się przy ogłoszeniu prawomocnego wyroku sądu odwoławczego. Co prawda z zasad deontologii zawodowej adwokata i radcy prawnego wynika, że są oni zobowiązani czuwać nad biegiem sprawy i informować klienta o jej postępach oraz wyniku ${ }^{27}$. Co do

27 Por. $\$ 49$ Zbioru Zasad Etyki Adwokackiej i Godności Zawodu (ogłoszony Obwieszczeniem Prezydium Naczelnej Rady minu do złożenia wniosku o doręczenie wyroku sądu odwoławczego z uzasadnieniem, oskarżony zazwyczaj nie może skutecznie argumentować, że nie dotrzymał go z powodu zaniedbań obrońcy, skoro w myśl art. $84 \$ 2$ k.p.k. obrońca nie ma bowiem obowiązku podejmowania czynności na jego rzecz. Trzeba jednak przyznać, że orzecznictwo w tym względzie nie jest jednolite. Niekiedy Sąd Najwyższy uwzględnia zażalenia skazanych na postanowienia o odmowie

Adwokackiej z dnia 27 lutego 2018 r. w sprawie ogłoszenia jednolitego tekstu Zbioru Zasad Etyki Adwokackiej i Godności Zawodu (Kodeks Etyki Adwokackiej); art. 44 Kodeksu Etyki Radcy Prawnego, Załącznik do uchwały Nr 3/2014 Nadzwyczajnego Krajowego Zjazdu Radców Prawnych z dnia 22 listopada $2014 \mathrm{r}$.

28 Por. $\$ 57$ Zbioru Zasad Etyki Adwokackiej i Godności Zawodu; art. 44 Kodeksu Etyki Radcy Prawnego. 
przywrócenia tego terminu, powołując się na utrwalony pogląd, mający swe oparcie w art. $86 \$ 1$ k.p.k., że oskarżony nie może ponosić negatywnych konsekwencji zaniedbań ze strony swojego obrońcy ${ }^{29}$. Dzieje się tak jednak jedynie wyjątkowo, jeżeli oskarżonemu uda się wykazać, że obrońca z urzędu zobowiązał on wprost, jak czynił to art. $419 \$ 2$ k.p.k. przed jego uchyleniem, przesłanek doręczenia wyroku, a jedynie wskazuje, pod jakimi warunkami termin do złożenia wniosku o sporządzenie na piśmie i doręczenie uzasadnienia wyroku rozpoczyna swój bieg od jego doręczenia.

\section{Przeprowadzone rozważania prowadzą do} wniosku, że minimalnym zabezpieczeniem skutecznego dostępu oskarżonego pozbawionego wolności i reprezentowanego przez obrońcę z urzędu do kasacyjnego etapu postępowania jest wprowadzenie do Kodeksu postępowania karnego obowiązku pouczania go.

się do wywiedzenia kasacji, a zatem także do złożenia wniosku o doręczenie wyroku z uzasadnieniem. Wówczas skazany może uzyskać przywrócenie terminu w razie zaniedbań obrońcy w tym zakresie ${ }^{30}$. Inaczej rzecz się przedstawia w razie reprezentowania oskarżonego przez obrońcę z wyboru. Nieuzgodnione $z$ oskarżonym zaniechanie przez tego obrońcę podjęcia czynności zmierzających do wywiedzenia kasacji $z$ reguły pozwala oskarżonemu na skuteczne podniesienie argumentu, że niedotrzymanie terminu, o którym mowa w art. $524 \$ 1 \mathrm{zd}$. drugie k.p.k., nastąpiło z przyczyn od niego niezależnych ${ }^{31}$.

Nie sposób też nie zauważyć, że redakcja przepisu art. $422 \S 2$ a k.p.k. jest nieprawidłowa. Nie definiuje

29 Por. R.A. Stefański (w:) R.A. Stefański, S. Zabłocki (red.), Kodeks postępowania karnego, t. 1: Komentarz do art. 1-166, Warszawa 2017, s. 998.

30 Postanowienie SN z dnia 9 sierpnia 2017 r., II KZ 18/17, Lex nr 2342168; Postanowienie SN z dnia 18 marca 2015 r., III KZ 31/15, Lex nr 1734691.

31 Por. np. Postanowienie SN z dnia 3 kwietnia 2019 r., V KZ 7/19, Lex nr 2649798.
Na gruncie zaprezentowanych uregulowań w najnowszym orzecznictwie przyjmuje się, że skoro skazany świadomie zrezygnował $\mathrm{z}$ doprowadzenia na rozprawę, to pogodził się z tym, że zapadnie wyrok prawomocnie kończący postępowanie, jak również z tym, że będzie zmuszony samodzielnie uzyskać wiedzę o tym rozstrzygnięciu. Sąd Najwyższy uznaje, że w tej sytuacji nie można uznać za usprawiedliwioną niewiedzy skazanego o tym, iż na rozprawie zapadł wyrok sądu odwoławczego, a także nieuzasadnione jest obciążanie przez skazanego obrońcy odpowiedzialnością za brak wiadomości w tym przedmiocie ${ }^{32}$.

Nie negując możliwości dokonania takiej wykładni obowiązujących przepisów, trzeba je uznać za istotnie obniżające poziom gwarancji procesowych dla oskarżonych pozbawionych wolności i reprezentowanych przez obrońców z urzędu. Niewątpliwie ustawodawca

32 Por. Postanowienie Sądu Najwyższego z dnia 20 grudnia 2018 r., V KZ 57/18, Lex nr 2626859; podobnie: Postanowienie SN z dnia 27 lutego 2018 r., III KZ 11/18, Lex 2450253; Postanowienie SN z dnia 26 czerwca 2019 r., IV KZ 20/19, Lex nr 2694542. 
może obniżyć poziom paternalizmu procesowego, przyjmując, że także oskarżony ma obowiązek dbać o swoje interesy procesowe i wykazywać się aktywnością w celu ich realizacji. Można to jednak uczynić pod warunkiem, że oskarżony będzie w pełni świadom konsekwencji niezłożenia wniosku o doprowa- oskarżonego o możliwości złożenia wniosku z art. 451 k.p.k. należy już obecnie wywodzić $\mathrm{z}$ art. $16 \$ 2$ k.p.k. ${ }^{33}$

Natomiast rozwiązaniem optymalnym najpełniej gwarantującym oskarżonemu możliwość skutecznego zainicjowania kasacyjnej kontroli orzeczenia byłoby wprowadzenie obowiązku doręczania oskarżonemu

\section{Kasacja staje się środkiem zaskarżenia, w którym} coraz częściej są podnoszone nie zarzuty rażącego naruszenia prawa skutkujące nierzetelną kontrolą odwoławczą, ale właśnie zarzuty rażącego naruszenia prawa przez sąd reformatoryjnie i na niekorzyść oskarżonego kształtujący jego sytuację prawną.

dzenie na rozprawę odwoławczą aktualizujących się już po ogłoszeniu orzeczenia. W przeciwnym razie za uzasadnione trzeba uznać wątpliwości, czy sposób uregulowania w k.p.k. dostępu do kasacyjnego etapu postępowania spełnia wymogi art. 6 ust. 1 Konwencji.

\section{Podsumowanie i propozycje de lege ferenda}

Przeprowadzone rozważania prowadzą do wniosku, że minimalnym zabezpieczeniem skutecznego dostępu oskarżonego pozbawionego wolności i reprezentowanego przez obrońcę z urzędu do kasacyjnego etapu postępowania jest wprowadzenie do Kodeksu postępowania karnego obowiązku pouczania go o tym, że: 1) obrońca wyznaczony z urzędu nie jest obowiązany podejmować czynności po ogłoszeniu orzeczenia (czyli o treści art. $84 \$ 2$ zd. pierwsze k.p.k.); 2) niezłożenie wniosku o doprowadzenie na rozprawę odwoławczą skutkuje tym, że prawomocny wyrok sądu odwoławczego nie zostanie mu doręczony; 3) w tych okolicznościach termin do złożenia wniosku o doręczenie wyroku z uzasadnieniem rozpocznie swój bieg od dnia ogłoszenia wyroku.

W świetle zasady lojalności procesowej obowiązek zawarcia takich pouczeń przy okazji informowania pozbawionemu wolności wyroku wydanego pod jego nieobecność, jeżeli nie ma obrońcy. Propozycję zmiany art. $422 \$ 2$ a k.p.k. zawierającą postulowane powyżej rozwiązanie zawierała pierwotna wersja projektu nowelizacji Kodeksu postępowania karnego, która weszła w życie dnia 5 października 2019 r. ${ }^{34}$ Niestety ostatecznie ustawodawca nie zdecydował się na wprowadzenie zmian w omawianym zakresie.

Tendencja do obniżania gwarancji procesowych oskarżonego w obrębie dostępu do kasacji musi nie-

33 W jednym z orzeczeń Sąd Najwyższy stwierdził, że brak pouczenia o treści art. $84 \$ 1$ i 2 zd. pierwsze k.p.k. nie może wywoływać ujemnych skutków dla skazanego. Stosując art. $16 \$ 2$ k.p.k., uznał, że brak takiego pouczenia powodował konieczność uchylenia zarządzenia o odmowie przyjęcia środka odwoławczego (zażalenia na zarządzenie o odmowie przyjęcia kasacji: Postanowienie SN z dnia 24 października 2001 r., IV KZ 60/01, OSNKW 2002, z. 1-2, poz. 10).

34 Zgodnie z projektem w wersji z dnia 8 grudnia 2018 r. art. 422 $\$ 2$ a miał otrzymać brzmienie: „\$2 a. Dla oskarżonego pozbawionego wolności, który nie ma obrońcy i nie był obecny podczas ogłoszenia wyroku, termin wymieniony w $\$ 1$ biegnie od daty doręczenia mu wyroku”. Projekt dostępny pod adresem: https://legislacja.rcl.gov.pl/docs//2/12318806/125 54727/12554728/dokument370960.pdf (dostęp: 11.01.2020). 
pokoić również w kontekście zmiany samego modelu postępowania odwoławczego. Kardynalne ograniczenie ochrony wynikającej z reguł ne peius w powiązaniu z dopuszczalnością prowadzenia postępowania dowodowego w instancji odwoławczej, czynienia na tym etapie nowych, niekorzystnych dla oskarżonego ustaleń faktycznych powoduje, że kasacja staje się środkiem zaskarżenia, w którym coraz częściej są podnoszone nie zarzuty rażącego naruszenia prawa skutkujące nierzetelną kontrolą odwoławczą, ale właśnie zarzuty rażącego naruszenia prawa przez sąd reformatoryjnie i na niekorzyść oskarżonego kształtujący jego sytuację prawną. Jeszcze przed dniem 1 lipca 2015 r. oskarżonemu pozbawionemu wolności i reprezentowanemu przez obrońcę z urzędu doręczano wyrok sądu odwoławczego, jeżeli nie był obecny przy jego ogłoszeniu, chociaż sąd odwoławczy nie był nawet władny orzec surowszej kary pozbawienia wolności, jeżeli zmieniał ustalenia faktyczne przyjęte za podstawę zaskarżonego wyroku. Obecnie oskarżonemu nie doręcza się wyroku tego sądu, chociaż w instancji odwoławczej może zostać po raz pierwszy orzeczona kara pozbawienia wolności, a nawet oskarżony może po raz pierwszy zostać skazany, pomimo że zaskarżonym wyrokiem warunkowo umorzono wobec niego postępowanie karne. W tych okolicznościach nie sposób zaakceptować obniżenia standardu dostępu do kasacyjnego etapu postępowania karnego.

\section{Bibliografia}

Eichstaedt K., Komentarz aktualizowany do art. 422 kodeksu postępowania karnego (w:) D. Świecki (red.), Kodeks postępowania karnego, t. 1: Komentarz aktualizowany, LEX/el., 2019.

Hofmański P., Zabłocki S., Kasacja w sprawach karnych a niektóre uwarunkowania wynikajace z zobowiazań traktatowych (w:) A. Błachnio-Parzych i in. (red.), Problemy wymiaru sprawiedliwości karnej. Księga jubileuszowa Profesora Jana Skupińskiego, Warszawa 2013.

Kulesza C., Obrońca (w:) (red. tomu) V. (red. nacz.)Strony i inni uczestnicy postępowania karnego. System Prawa Karnego Procesowego, t. 6, Warszawa 2016.

Sakowicz A. (red.), Kodeks postepowania karnego. Komentarz, Warszawa 2018.

Smarzewski M., Granice efektywności prawa do korzystania $z$ pomocy obrońcy w kontekście ostatnich nowelizacji KPK, „Monitor Prawniczy” 2016, z. 21.
Stefański R.A. (w:) (red.)Kodeks postępowania karnego, t. 1: Komentarz do art. 1-166, Warszawa 2017.

Steinborn S., Ograniczenia zaskarżalności wyroku wydanego w I instancji jako środek uproszczenia procesu karnego w świetle prawa do dwuinstancyjnego postępowania (uwagi de lege lata i de lege ferenda), „Gdańskie Studia Prawnicze” 2005, t. 13.

Świecki D., Czynności procesowe obrońcy i petnomocnika w sprawach karnych, Warszawa 2018.

Świecki D., Wniosek o sporządzenie na piśmie i doręczenie uzasadnienia wyroku (w:) Konstrukcja apelacji jako środka odwoławczego w procesie karnym, Warszawa 2018, wersja elektroniczna. Wąsek-Wiaderek M., Prawo oskarżonego do realizowania obrony na rozprawie w świetle ostatnich zmian kodeksu postępowania karnego (w:) (red.)Proces karny w dobie przemian. Przebieg postępowania, Gdańsk 2018.

Wąsek-Wiaderek M., Proces karny a międzynarodowe standardy w dziedzinie praw człowieka (w:) V. Hofmański (red.), System Prawa Karnego Procesowego. Zagadnienia ogólne, t. 1, cz. 2 Warszawa 2013.

Wąsek-Wiaderek M., Standard ochrony praw oskarżonego w świetle Europejskiej Konwencji Praw Człowieka (w:) C. Kulesza (red. tomu), V. Hofmański (red. nacz.), Strony i inni uczestnicy postępowania karnego. System Prawa Karnego Procesowego, t. 6, Warszawa 2016.

\section{Orzecznictwo}

\section{Orzeczenia Sądu Najwyższego}

Postanowienie SN z dnia 24 października 2001 r., IV KZ 60/01, OSNKW 2002, z. 1-2, poz. 10.

Postanowienie SN z dnia 3 lutego 2012 r., V KZ 1/12, OSNKW 2012, z. 6, poz. 58 .

Wyrok SN z dnia 19 lutego 2013 r., IV KK 200/12, OSNKW 2013, z. 4, poz. 32.

Postanowienie SN z dnia 18 września 2013 r., V KZ 60/13, Lex nr 1363213

Postanowienie SN z dnia 18 marca 2015 r., III KZ 31/15, Lex nr 1734691.

Postanowienie SN z dnia 24 maja 2016 r., V KZ 19/16, Lex nr 2044504.

Postanowienie SN z dnia 22 czerwca 2016 r., III KZ 39/16, OSNKW 2016, z. 12, poz. 80 .

Postanowienie SN z dnia 13 lutego 2017 r., III KZ 91/16, Lex nr 2238696. 
Postanowienie SN z dnia 9 sierpnia 2017 r., II KZ 18/17, Lex nr 2342168.

Postanowienie SN z dnia 14 grudnia 2017 r., III KZ 56/17, Lex nr 2427121.

Postanowienie SN z dnia 27 lutego 2018 r., III KZ 11/18, Lex nr 2450253.

Postanowienie SN z dnia 20 grudnia 2018 r., V KZ 57/18, Lex nr 2626859.

Postanowienie SN z dnia 23 stycznia 2019 r., III KZ 60/18, „Supremus" (www.sn.pl).

Postanowienie SN z dnia 3 kwietnia 2019 r., V KZ 7/19, Lex nr 2649798.

Postanowienie SN z dnia 26 czerwca 2019 r., IV KZ 20/19, Lex nr 2694542.

\section{Orzeczenia Europejskiego Trybunału Praw \\ Człowieka}

Decyzja ETPC z dnia 7 września 1999 r., Jodko v. Litwa, skarga nr 39350/98.
Wyrok ETPC z dnia 18 grudnia 2001 r., R.D. v. Polska, skargi nr 29692/96 i 34612/97.

Wyrok ETPC z dnia 1 marca 2006 r., Sejdovic v. Włochy, skarga nr 56581/00.

Wyrok ETPC z dnia 19 maja 2009 r., Kulikowski v. Polska, skarga nr 18353/03.

Wyrok ETPC z dnia 19 maja 2009 r., Antonicelli v. Polska, skarga nr 2815/05.

Wyrok ETPC z dnia 25 czerwca 2009 r., Maresti v. Chorwacja, skarga nr 55759/07.

Wyrok ETPC z dnia 3 listopada 2009 r., Davran v. Turcja, skarga nr 18342/03.

Wyrok ETPC z dnia 13 września 2011 r., Wersel v. Polska, skarga nr 30358/04.

Wyrok ETPC z dnia 29 kwietnia 2014 r., Natsvlishvili and Togonidze v. Gruzja, skarga nr 9043/05.

Wyrok ETPC z dnia 15 września 2016 r., Johansen v. Republika Federalna Niemiec, skarga nr 17914/10.

Wyrok ETPC z dnia 4 kwietnia 2018 r., Correia de Matos v. Portugalia, skarga nr 56402/12. 